\title{
Ao gosto do freguês: as manifestações afro-bra- sileiras no Carnaval do Rio de Janeiro no início do século XX como busca de uma modernidade'
}

\author{
Ana Carolina Cometti Oliozi" e Handerson de Menezes Lopes ${ }^{I I I}$ e Raquel Fernandes ${ }^{\text {IV }}$ \\ Resumo: O trabalho traz reflexões acerca da inserção de aspectos da afrobrasilidade no Carnaval carioca. \\ A ideia é unir tradição e modernidade na construção de uma identidade com a absorção de elementos da \\ cultura afro-brasileira na festa oficial a partir de um desejo da elite e da classe política.
}

Palavras-chave: Carnaval. Modernidade. Afro-brasileira. Miscigenação.

\section{To the customer's taste: Afro-Brazilian manifestations at the Rio de Janeiro Carnival in the early 20th century as a search for modernity}

\begin{abstract}
The paper addresses reflections about the insertion of aspects of Afro-Brazilianness in the Carnival of Rio de Janeiro. The idea is to combine tradition and modernity in constructing an identity with the absorption of elements of Afro-Brazilian culture in the official festivity, under the wishes of the elite and the political class.
\end{abstract}

Keywords: Carnaval. Modernity. Afro-brazilian. Miscegenation.

I Este artigo foi realizado no âmbito do projeto "História da Arte Global" do Programa de Pós-Graduação em História da Arte da UERJ, o qual conta com apoio financeiro da FAPERJ (Edital n. 12/2019).

II Doutoranda em História da Arte no Programa de Pós-graduação em História da Arte da Universidade do Estado do Rio de Janeiro (PPGHA/UERJ), mestra pelo Programa de Pós Graduação em Mídia e Cotidiano da Universidade Federal Fluminense (UFF) e bacharel em Comunicação Social - Jornalismo pela Universidade Federal do Espírito Santo (Ufes). Discente da Universidade do Estado do Rio de Janeiro - R. São Francisco Xavier, 524 - Maracanã, Rio de Janeiro - RJ, 20550-013. E-mail: anycometti@gmail.com, ORCID: https://orcid.org/0000-0002-66971550?lang=pt. Lattes iD: http://lattes.cnpq.br/7850775186796479. Vitória, Brasil.

III Mestrando em História da Arte no Programa de Pós Graduação em História da Arte da Universidade do Estado do Rio de Janeiro (UERJ), Graduado em História na Universidade Federal do Rio de Janeiro (UFRJ). Discente da Universidade do Estado do Rio de Janeiro - R. São Francisco Xavier, 524 - Maracanã, Rio de Janeiro - RJ, 20550-013. E-mail: handerson.lopes@gmail.com. ORCID: https://orcid.org/0000-0002-8743-4869 . Lattes iD: http://lattes. cnpq.br/1019250234757248. Rio de Janeiro, Br.

IV Doutoranda em História da Arte no Programa de Pós-graduação em História da Arte da Universidade do Estado do Rio de Janeiro (PPGHA/UERJ). Mestre em Artes (PPGArtes/UERJ). Especialista em Literatura, Memória Cultural e Sociedade pelo IFFluminense - Campus Campos Centro. Licenciada em Artes Visuais pela UNIVERSO e Bacharel em Teatro pela Universidade do Rio de Janeiro (UNIRIO). Docente do IFFluminense - Campus Campos Centro. E-mail: africanandes@gmail.com. ORCID: https://orcid.org/0000-0002-3418-5336. Lattes iD: http://lattes.cnpq. br/5330896047503665. Campos dos Goytacazes, RJ, Brasil. 


\section{Introdução}

Pensar o Carnaval a partir do que vemos hoje como uma construção natural das multidões é um ato bastante ingênuo. No decorrer desse texto seremos chamados a refletir e dialogar não apenas sobre certas transformações ocorridas no segundo quartel do século XX na cidade do Rio de Janeiro, mas também sobre alguns conceitos importantes que permeiam essa construção de uma identidade afro-brasileira e suas implicações. A partir desta premissa, o texto traz como recorte a presença constante, assimilada por boa parte da sociedade, da representação de vários aspectos da cultura afro-brasileira como produto de exportação da imagem de um Brasil miscigenado, pacificado, múltiplo e moderno.

É evidente que, quando se fala em moderno, se faz importante pensar na amplitude do termo e em tudo que implica essa ideia. Em um debate recente sobre a modernidade brasileira, a professora e pesquisadora Marize Malta (2021) traz algumas reflexões que podem ser utilizadas como referência para o moderno que estamos tentando ilustrar com as questões levantadas neste trabalho. O moderno era encarado também no Rio de Janeiro como uma multiplicidade de possibilidades onde poderiam coexistir referências paradoxais ou complementares: como um "velho e um outro novo mundo", uma terra que é ao mesmo tempo "agrícola e progressista", uma cidade "mestiça e mundana", "idílica e veloz", e outras características de diversos tempos e sentidos.

Desde as últimas décadas do século XIX, mais do que qualquer outra cidade, a capital do país sentiu no seu cotidiano os ventos da modernidade, buscando um modo particular de civilizar-se, e ao mesmo tempo, cair no samba e nas folias carnavalescas. (MALTA, 2021)

Foi pelo Carnaval e pelo samba que, segundo Malta, a maioria minoritária se fez ver e ouvir, figuras icônicas da cultura vindas dos morros foram descendo para as ruas da cidade e conquistando o signo de modernidade e contradições. Um país dividido em classes bem definidas e repletas de diversas espécies de exclusões instaura o malandro e a baiana como símbolos de brasilidade, miscigenação e construção de um discurso oficial que parte de uma ideia de uma cultura afro-brasileira.

Mas a quem interessa essa ideia? A escrita propõe a priori entender historicamente os elementos carnavalescos dessa festa popular, ao mesmo tempo que traz o cenário sócio-cultural e o Carnaval da década de 1930. A inserção de aspectos mais elaborados e carnavalescos nos desfiles, a organização dos mesmos e, em seguida, signos selecionados para conferir à festa identidade afro-brasileira. A partir deste ponto se faz necessário pensar esse conceito afro-brasileiro e sua ligação com o processo de busca de uma modernidade 
para a nação. Era importante avançar socialmente e o Carnaval poderia servir como uma grande vitrine que mostra os avanços do país e o exotismo da sua miscigenação.

\title{
O Carnaval e o carnavalesco
}

A história do Carnaval permeia uma infinidade de marcos e inícios desde os povos do Antigo Egito, da Grécia Antiga, dos Romanos e também das culturas cristãs. Não iremos nos aprofundar aqui na história detalhada do Carnaval, pois seria um outro trabalho, mas passaremos por alguns eixos significativos que facilitarão a abordagem do tema. É importante pensarmos que o Carnaval, enquanto data e símbolo de uma festa pagã, se dá a partir do momento em que a Igreja, durante a Idade Média, institui a Quaresma. A Quaresma é um período de quarenta dias em que os fiéis fazem o jejum da carne, que pode ser interpretado de forma literal ou não. Pode ser a carne da qual nos alimentamos ou, de forma metafórica, dos pecados da carne que envolvem, entre outras coisas, os prazeres do corpo e do espírito. Este jejum, para a Igreja, simbolizará os quarenta dias antes da Páscoa que antecedem a Paixão de Cristo: prisão, crucificação e ressurreição.

\begin{abstract}
Resta também pouca dúvida com relação à ligação entre as celebrações festivas das antigas civilizações e as loucuras da folia contemporânea. Apesar disso, não dá pra afirmar que já existia Carnaval no Antigo Egito ou nas civilizações greco-romanas, [...] as festas em homenagens à deusa Ísis egípcia ou ao deus Baco romano, entre outras tantas, não são festas carnavalescas nem precursoras somente do Carnaval, mas sim de todos os tipos de festas públicas populares que o mundo conheceu depois delas, [...]. (FERREIRA, 2004; p. 16)
\end{abstract}

Na citação acima, o autor é bem didático ao nos explicar que as festas populares sempre existiram e seu texto nos aponta um caminho onde podemos entender que a cultura popular e as manifestações de alegria e diversão são inerentes ao advento da Quaresma, mas, ao mesmo tempo, podem ter sofrido transformações a partir desta novidade vinda da Igreja.

Muitas dessas festas anteriores ao início desse marco possuíam características que hoje podemos considerar aspectos "carnavalescos". Como grandes comemorações, música, dança, muitas pessoas, comes e bebes e troca de papéis na sociedade "entre o rei e um mendigo" por exemplo, como aponta o autor citado acima. Mas nem por isso era Carnaval. "Uma está na raiz da outra, mas não é a mesma coisa”. (FERREIRA, 2004; p. 17).

Para pensar tanto no Carnaval quanto no que seria Carnavalesco, vamos buscar referência no pensamento de Bakhtin colocado por STOREY (1998). 
Segundo o autor, Bakhtin traz uma ideia de que no Carnaval não há divisão entre artistas e espectadores, todos participam e performam o Carnaval. Dessa maneira, os papéis sociais são diluídos ou até mesmo invertidos. Os participantes, segundo ele, vivem um momento de atitudes carnavalescas, fora do seu ciclo habitual; é como se a vida virasse do avesso "the reverse side of the world, ('monde à l'envers')" (STOREY, 1998; p.251).

Ainda dentro deste pensamento, uma questão bem relevante para nos fazer refletir na estrutura que constrói um comportamento dentro de um Carnaval burguês no Brasil, é o sentido carnavalesco do mundo. Segundo Storey, Bakhtin também aborda a inusitada aproximação entre as pessoas e a desestruturação momentânea de uma hierarquia social. Há uma suspensão da ordem da vida, das leis e das estruturas sociais.

Para Bakhtin o carnaval unifica, reúne e combina sagrado com profano, o grande com o insignificante e dessa forma, permite ações, manifestações, expressões sociais e culturais que normalmente não seriam permitidas pela sociedade dominante. Para o autor, há entre as categorias de um comportamento ou de uma festa com aspectos Carnavalescos a ideia de profanação, paródia, caricatura e exagero, cunhada ao longo de milhares de anos em festas e manifestações com essas características, mesmo ainda não sendo Carnaval.

Nessa festa, ao contrário, é dado um sinal de que todos podem se comportar do modo mais louco e tolo que quiserem, e que, com exceção de socos e golpes de faca, tudo o mais é permitido. [...] Todos se aproximam de todos, cada um agarra, com facilidade, aquilo que vem ao seu encontro, e a ousadia e a liberdade se alternam uma à outra, sendo equilibradas por um bom humor geral. (GOETHE, 2017; p.525)

Observamos acima o texto de Goethe em seu livro Viagem à Itália onde ele dedica um grande capítulo para descrever em detalhes o Carnaval romano. No trecho, observa-se que o autor enfatiza o comportamento diferenciado, fora do padrão social e até mesmo tolo. O momento onde as manifestações comportamentais mais diferentes e inaceitáveis poderão ser aceitas e divertidas. Todos ali, povo, elite e Igreja têm a consciência de que é apenas momentâneo; a extravagância festiva é característica desse período de exagero que acabará na quarta-feira de cinzas, quando a vida voltará à normalidade.

Podemos imaginar que o Carnaval chega ao Brasil enquanto festividade que marca o início da Quaresma com os colonizadores portugueses já no século XVI. Devido à religiosidade católica vinda para o Brasil colônia e imposta a todos os habitantes daqui, obviamente esse costume das brincadeiras do período do Carnaval atravessou o Atlântico e ganhou novas formas. 
Figura 1

Jean-Baptiste Debret Cena de Carnaval, 1823

Litografia, s.d, Viagem Pitoresca ao Brasil, Jean-Batiste Debret

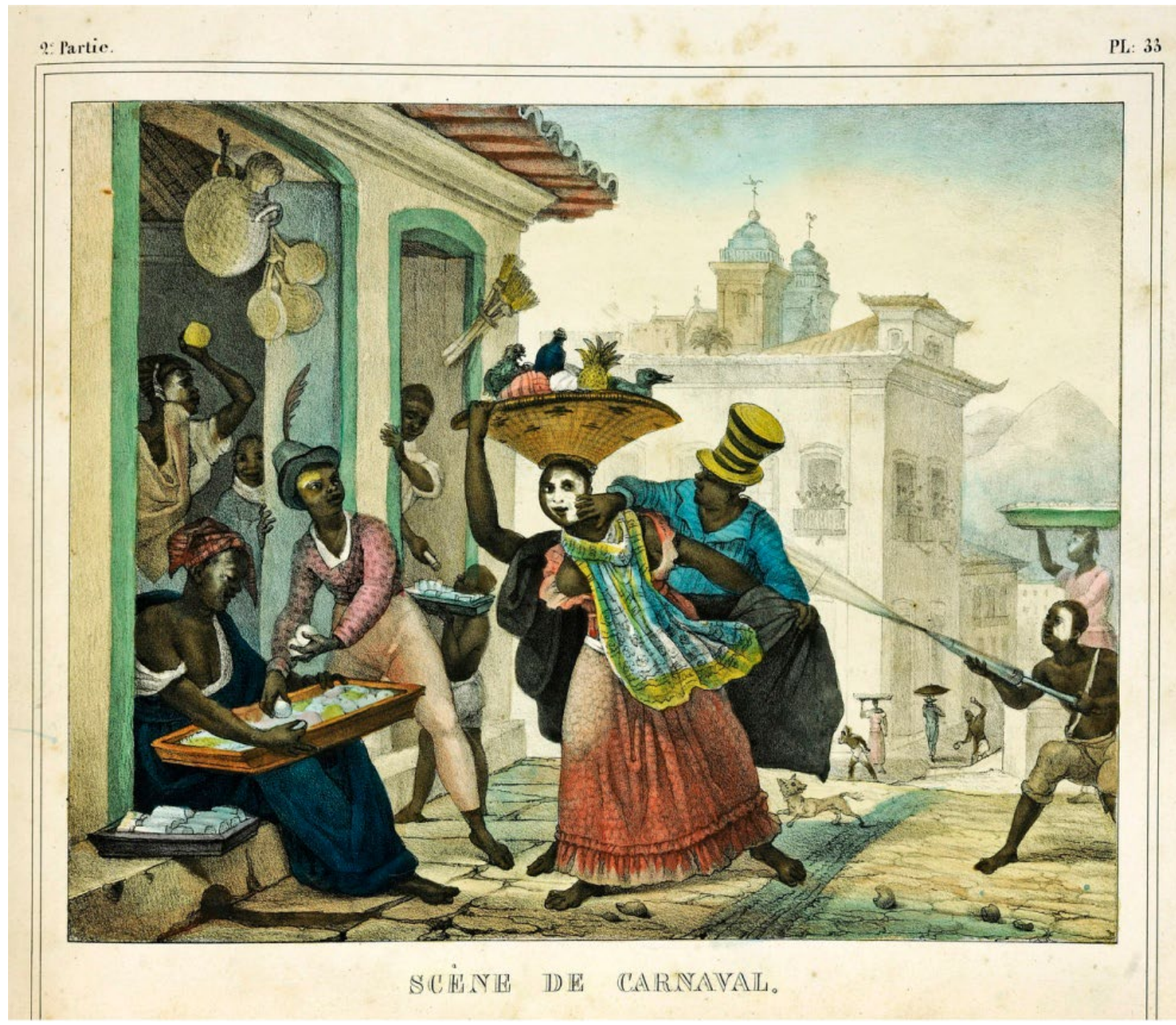

Ao observar uma cena realmente bem pitoresca e talvez alegórica do modo como se configurava o carnaval e/ou as festas populares na Colônia da litogravura de Debret (1823) nos deparamos com a imagem de um Brasil que a elite gostaria de deixar no passado ao adentrar no século XX. Em seu relato visual do Brasil, o artista ilustrou e materializou em alguns de seus trabalhos uma ideia de uma festa livre, um tanto desorganizada, dominada pelos negros e que poderia trazer riscos às damas e/ou aos cavalheiros da alta sociedade. Outras formas de diversão começavam a ser praticadas pela elite, porém, em suas casas, de modo particular, para não se misturarem aos negros e mestiços.

Inicialmente, segundo o relato no Livro de Ouro do Carnaval Brasileiro, de Felipe Ferreira (2004), a festa acontecia a princípio como "molhadelas e enfarinhamentos", como podemos observar na imagem anterior, no mesmo modelo dos "Entrudos" europeus, onde os brincantes atiravam pó com diversas tonalidades nos seus "oponentes". A festa se dividia em dois grupos: 
...um que acontecia dentro das casas e entre amigos e que chamaremos de "familiar" e outro que tomava conta das ruas, envolvendo basicamente a população mais pobre e os escravos, que denominaremos de "popular". (FERREIRA, 2004; p. 81)

\section{O Rio de Janeiro e o Carnaval}

Muitos diálogos comportamentais aconteceram e provocaram diversas reformulações. As brincadeiras do período do Carnaval foram se modificando e 300 anos se passaram até uma grande transformação política trazer para a colônia outra roupagem para as manifestações culturais e o comportamento social. A vinda da Família Real no século XIX trouxe também outros costumes e não seria diferente com o Carnaval.

Com a vinda da coroa portuguesa em 1808, fato inédito na história da expansão e colonização europeias, (uma corte se instalar em uma colônia e fora da Europa), muitos costumes também vieram e por conta de várias razões, predominaram os costumes franceses. A França estava na moda. (FERREIRA, 2004). A missão francesa trazida por D. João VI em 1816 trouxe uma ideia de modernidade, liberdade e civilidade. Após a Independência do Brasil, essa influência ficou ainda mais explícita e foi surgindo uma ideia, assim como na Europa, de que tudo que vinha da França era moderno, ao contrário dos costumes que vinham de Portugal, que eram considerados atrasados.

Com a influência dos costumes franceses, o modelo de Carnaval que se baseava nas brincadeiras do "Entrudo", segundo Ferreira (2004), vai se distanciando cada vez mais da elite que quer se aproximar da alta aristocracia francesa fazendo surgir os bailes de máscaras. O "Entrudo" foi ficando mal visto e até mesmo, por algum tempo, seus brincantes eram perseguidos, detidos e impedidos de praticar este costume tão popular.

Os bailes, a partir do século XIX, foram marcados por luxo e exclusividade, enquanto que o povo brincava na rua e, muitas vezes, ignorava as proibições. Assim como na História do Carnaval no mundo, muitos fatos e diálogos aconteceram e foram transformando essa festa; no Brasil não foi diferente. Não vamos tecer aqui detalhes da História do Carnaval no Brasil, mas focaremos principalmente no surgimento da necessidade de inserção de uma ideia de africanidade no Carnaval, para que a imagem de um país miscigenado e exótico atendesse ao gosto do pensamento de uma nova elite que se formava e do turista estrangeiro no século XX. 
As ruas do centro do Rio de Janeiro foram atores importantes para a organização da folia nacional. Elas representaram não somente o palco preferencial das sociedades carnavalescas, ao estilo da elite, como também se estabeleceram como o espaço que iria permitir e incentivar o surgimento dos grupos carnavalescos populares. É através das disputas e diálogos ocorridos nessas estreitas vias que o Carnaval carioca começaria a estruturar a festa que seria o modelo para todo o país. (FERREIRA, 2004; p.157)

Figura 2 Augusto Malta. Desfile das Grandes Sociedades Carnavalescas, 1919. Fotografia, s.d.. Fonte: https://pt.wikipedia. org/wiki/Ficheiro:Des-

file_das_grandes_sociedades_carnavalescas,_Acervo_do_Instituto_Moreira_Salles.

jpg, Acervo Instituto Moreira Sales
Muitas águas rolaram neste percurso da construção do Carnaval que temos hoje: dos cortejos da elite, protegidos por homens montados a cavalo para se chegar aos Bailes; da criminalização dos entrudos; das procissões com andor, imagens e painéis pintados aos desfiles das grandes sociedades e sumidades organizados com fantasias e carruagens decoradas; aos percursos definidos e delimitados pela elite da sociedade nas ruas do centro do Rio de Janeiro na tentativa de controlar a festa; até grupos de populares que se organizavam para sair pelas ruas tocando e exibindo, ou melhor, externalizando suas fantasias.

$\mathrm{Na}$ imagem anterior, podemos observar um desfile das grandes sociedades carnavalescas guardando ainda um espaço privilegiado para a elite. A

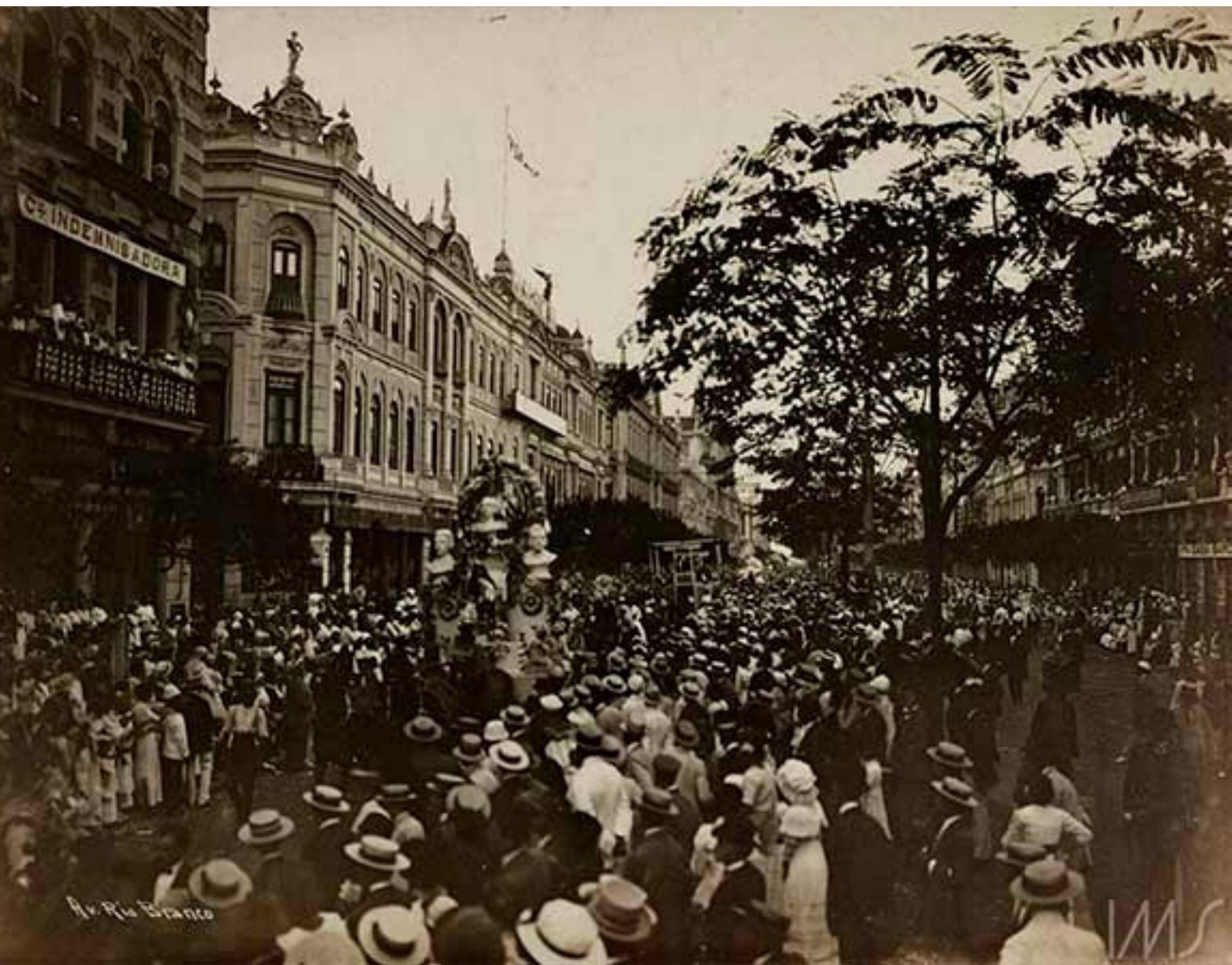


fotografia nos mostra um carro enfeitado com efeitos e símbolos que alegram e divertem os populares que se espalham pelas ruas. Uma festa produzida pela alta sociedade para ser oferecida ao povo, que neste momento, assiste ao desfile e se diverte com as diversas performances.

Este momento é transitório e anterior à passagem para o surgimento de um conceito de brasileiro e brasilidade que irá se instaurar na década de 30. Segundo Schwarcz e Starling (2015), o brasileiro nasce onde começa a mestiçagem. Porém, é a partir dessa miscigenação, no entanto, que se constroem ao mesmo tempo as permanências e os apagamentos.

A mistura deixou de ser desvantagem para tornar-se elogio, e diversas práticas regionais associadas ao popular - na culinária, na dança, na música, na religião - seriam devidamente desafricanizadas por assim dizer. Transformadas em motivo de orgulho nacional, foram aclamadas, e são até hoje consideradas, marca da originalidade cultural do país (SCHWARCZ; STARLING, 2015; p. 378)

Por mais complexa que seja essa trajetória, com muitas negociações, disputas, transformações, adaptações de costumes, lutas de classe e conquistas de território, o Carnaval na capital brasileira, Rio de Janeiro, vai se transformando até chegar aos dias de hoje. Mas duas ideias são importantes de serem destacadas para permear o restante do nosso texto que fora citada até aqui: a presença de uma africanidade e negritude no Carnaval como uma bandeira de originalidade, modernidade e brasilidade em determinado momento dessa história; e a inversão de papéis e hábitos personificados pelas fantasias e comportamentos durante a festa, já citado tanto por Goethe quanto por Bakhtin, que permitiam aos brincantes serem nesses dias de folia o que não eram ou não podiam ser no restante do ano.

\section{Representação afro-brasileira como símbolo de modernidade}

Para entrar no cerne desta questão é necessário tentarmos refletir sobre esse aspecto e/ou conceito que chamamos de afro-brasileiro. Roberto Conduru (2007) traz em seu livro Arte Afro-Brasileira uma abordagem que parece pertinente ao tema tratado aqui. Definir uma estética ou mesmo a arte como afro-brasileira se torna uma ação bastante complexa porque prescinde de uma definição anterior do que seria africano e do que seria brasileiro. Pensando na África como um continente onde coexistem muitas nações, culturas diversas e características múltiplas e o Brasil como um país com uma dimensão continental que recebeu e ressignificou várias influências, seria bem reducionista definirmos uma estética afro-brasileira de forma tão simplória. Deste modo usaremos aqui a ideia de encontro com 
a encruzilhada que a afro-brasilidade nos encaminha, do mesmo modo que o autor nos revela em seu estudo:

\begin{abstract}
Nesse sentido, a expressão arte afro-brasileira indica não um estilo ou um movimento artístico produzidos apenas por afro-descendentes brasileiros, ou deles representativos, mas um campo plural, composto por objetos e práticas bastante diversificados, vinculados de maneiras diversas à cultura afro-brasileira, a partir do qual tensões artísticas, culturais e sociais podem ser problematizadas estética e artisticamente. (CONDURU, 2007; p.11)
\end{abstract}

No entanto, quando nos referirmos à estética afro-brasileira nesse trabalho, ou mesmo quando a partir daqui abordarmos o interesse da elite carioca de absorver tais elementos, estaremos nos referindo à influência dos povos negros africanos escravizados recém libertos da escravidão, mas ainda presos a sua origem, que trarão para o Brasil seus saberes e transformarão suas manifestações em um novo território com diversos outros elementos. Sendo assim, para entender a afro-brasilidade se faz necessário um diálogo constante nos diferentes campos do conhecimento que vai desde as dimensões geopolíticas, culturais e históricas até ao sentimento diaspórico de luta, negociação e sobrevivência.

É importante observarmos alguns fatores relevantes da cultura dos negros escravizados no Brasil que também foram se infiltrando nos costumes da elite burguesa. Após a abolição da escravatura, em 1888, há registros de que $80 \%$ da população do Rio de Janeiro era composta por negros. Retirados de suas nações e trazidos à força para o Brasil por muitos anos, centenas de milhares de homens e mulheres traziam na sua bagagem nada além da cultura e suas memórias. Obrigados a esquecerem sua fé, sua família, seus costumes e, muitas vezes, sua língua, os africanos e seus descendentes na Colônia se agarraram a algumas fendas no modus vivendi daqui para não sucumbirem. Juntamente com seus sentimentos de sobrevivência e luta, contando com a memória e a prática da espiritualidade, deixaram florescer uma diversidade cultural que podemos encontrar trançada em diversas manifestações no Brasil: na religião, na culinária, no comportamento, na música, na dança, entre outras.

As religiões de matrizes africanas foram proibidas de serem praticadas aqui ao longo de quase toda a história, assim como todas as suas festas e costumes. Eram politeístas, unificavam o povo negro, conferiam força e fé aos escravizados e iam contra os dogmas e as leis da Igreja Católica. Os negros eram batizados à força antes mesmo de entrarem nos navios negreiros e aqui, já no solo brasileiro, tinham que rezar na mesma cartilha. Com muita 
luta, resistência e transformações, o sincretismo religioso e cultural aconteceu no Brasil e, dessa forma, os negros formataram aqui cultos religiosos e festas que mesclavam signos do catolicismo e das suas religiões de origem. Exemplos mais conhecidos dessas manifestações sincréticas estão nas Igrejas das Ordens que surgem para receber a população negra e mestiça e as festas populares religiosas que misturam danças, música e representações simbólicas das mais diversas. Como Nossa Senhora da Conceição, São Jorge, Nossa Senhora Aparecida; e também os terreiros de Candomblé e a Umbanda. Estes últimos sofrendo desde sempre inúmeras proibições e retaliações, como acontecem até os dias atuais, mesmo sendo permitidos os cultos hoje no Brasil.

No final do século XIX, houve por grande parte da elite brasileira um esforço para colocar em prática uma ideia de embranquecimento da população como forma de construir uma identidade nacional, mostrando pureza e superioridade. Para isso, era importante apagar a presença maciça do negro e criar diversos estímulos a uma nova onda de migração de europeus para cá. Já no início do século XX, após a Primeira Guerra Mundial, outros conceitos, vindos de outras origens, permearam a busca de uma nacionalidade brasileira que incluiria uma identidade mais diversa com as múltiplas identidades que já havia nesse país. Ferreira (2014) ainda cita a Semana de Arte de 22 e o livro Casa Grande e Senzala de Gilberto Freyre, como um importante momento de ratificação da construção desse novo olhar para essa nova brasilidade que se buscava construir.

Novamente muitos diálogos e negociações ocorreram e o Carnaval Carioca passou a ser o símbolo do Carnaval no Brasil, até que outros lugares pudessem, ao longo do século, buscarem suas identidades.

O Carnaval passava a representar a síntese do Brasil. Não mais uma festa com um formato específico, mas uma reunião de diversas festas e ritmos populares. A folia carnavalesca propiciaria, desse modo, uma epifania, um momento de intenso contato com a "verdade" nacional. (FERREIRA, 2004; p. 255)

Para dar continuidade a esse pensamento e fazer o retorno ao nosso tema é importante pensar na ideia catártica do Carnaval, esse espírito carnavalesco onde o que é proibido é permitido, que Bakhtin nos chamou atenção. E também refletir sobre qual seria essa verdade nacional citada pelo autor vista pela elite brasileira.

No início do século XX, o Carnaval carioca se configura na grande festa nacional. Muitas transformações foram ocorrendo ao longo dos anos que 
antecederam esse movimento no Brasil - como o surgimento dos ranchos, blocos e cordões, a organização dos desfiles - até chegar nas escolas de samba, nos concursos e na grande festa universal. Retomo aqui o recorte de pensar sobre a representação afro-brasileira no Carnaval carioca como elemento para conferir modernidade e, ao mesmo tempo, ser espaço de resistência, mistura de diferentes formas de vivenciar a cultura, negociação e insubordinação para além da permissão da elite conservadora cristã. A festa se configura como um espaço constante de articulação e pertencimento do "espaço urbano carioca" como define Ferreira (2004).

Passado o final do século XIX, onde a regra era branquear a população, a intelectualidade brasileira passa por um processo de reinventar o símbolo da República com o movimento de buscar uma brasilidade e uma ideia de modernidade. Essa ação no início do século XX compreende, entre outras coisas, se afastar das características que aproximassem o país de Portugal e se imbuir dos costumes e do gosto que colocassem essa "nova" nação mais próxima dos costumes franceses. A arte moderna e os ideais modernistas vindos da França, principalmente com o cubismo de Picasso e o furor dos europeus pela arte africana fazem crescer o interesse da alta classe e da intelectualidade do Brasil. Mas, como diria Carl Einstein (1915, apud O'NEILL e CONDURU, 2015, p.29) “... o juízo até então atribuído ao negro e a sua arte caracterizou muito mais quem emitia tal juízo do que seu objeto". Dessa forma, houve pela Europa uma busca e uma necessidade constante de entrar em contato e colecionar a arte africana. Estas manifestações culturais de origem africana que se configuram no Brasil, fazem com que a elite intelectual brasileira comece a desejar, admitir, ou mesmo, prestar atenção no banquete de cultura negra que se apresentava por aqui. Nos anos de 1920, o movimento da construção de uma ideia de nação se fortalece e vários escritores, músicos e artistas plásticos fazem o movimento de resgatar os personagens que dariam nova unidade a nação.

\footnotetext{
Procurava-se então reunir a diversidade cultural do Brasil numa ideia homogênea. Esse projeto de construção de uma unidade identitária nacional faria, por exemplo, com que muitos artistas de formação erudita, incorporassem motivos populares em seus trabalhos como fez o Maestro Villa-Lobos, que juntou instrumentos típicos da congada à apresentação de sua orquestra na Semana de Arte Moderna de 22. (FERREIRA, 2004; p. 250)
}

Embora essa ação de mestiçagem estética e cultural não fosse um consenso geral, essas negociações foram acontecendo e dentro da perspectiva da ideia do Carnaval como a festa do povo, ela foi se reformulando e absorvendo diversas características. Se a ideia da festa, resgatando Goethe e 
Bakhtim, era ser o que normalmente não se podia ser, trocar os papeis ou mesmo brincar com as hierarquias, não seria mal nenhum absorver nos dias de folia novos elementos da cultura vinda da África como uma forma moderna e exótica de construir essa nova ideia de nação e se aproximar do modernismo francês. A folia carnavalesca, segundo Ferreira (2004), passa a ser uma fuga de distração para a luta cotidiana. Uma espécie de caldeirão "antropofágico" onde tudo é capaz de se transformar.

\section{Considerações finais}

As grandes sociedades desfilavam com seus carros alegóricos ricamente decorados pelas ruas do chamado Grande Carnaval no apagar do século XIX e no despertar do século XX. Era uma festa oferecida ao povo em carros ornamentados e com temáticas diversas. Por outro lado, uma "confusão carnavalesca" (TURANO e FERREIRA, 2013) formada por grupos populares se formava nas ruas da cidade. Aos poucos, as diferenças foram se intensificando e o Rio de Janeiro tinha bem definido três estilos claros de manifestações populares no carnaval: os cordões, os blocos e os ranchos.

A brincadeira do "Entrudo", destinada aos negros, havia sido criminalizada e perseguida, embora continuasse em vários formatos e espaços. Os cordões, ranchos e blocos eram evitados e foram alçados a um carnaval menor chamado de Pequeno Carnaval; já as Sociedades Carnavalescas, os Bailes e os cortejos da elite formaram um carnaval mais prestigiado, chamado de Grande Carnaval. Com o tempo os ranchos passam a ser mais suaves e os cordões considerados mais agressivos. Os blocos ficam no meio termo dessas características e saem às ruas também com ritmos, danças e fantasias. Os ranchos se sofisticam e vão perdendo um pouco sua originalidade. Desfilarão no cortejo nobre do Carnaval, mas se afastarão das raízes das ruas.

Havia então um dilema que aos poucos foi sendo resolvido pela sociedade a partir do convívio, das experiências e da força governamental e popular. Se por um lado os ranchos se sofisticaram e se distanciaram, por outro, os cordões ainda inspiravam a ideia de desordem. Nesse momento que a intelectualidade passa a olhar para o morro e favelas, identifica uma manifestação que poderia reunir as características necessárias para conferir ritmo, alegria, identidade afro-brasileira à folia e se aproximar da ideia de essência, tradição e modernidade: as escolas de samba. Esses grupos se destacavam e se diferenciavam de todos os outros não só pela organização, mas também pelos instrumentos e pelo novo ritmo que ecoava um samba batucado. Era segundo (TURANO e FERREIRA, 2013) "uma expressão carnavalesca capaz de representar o povo brasileiro em sua "essência", "tradicionalidade" e "inocência"”. 
O século XX avança, e partindo ainda dessa mesma ideia de buscar uma nacionalidade brasileira para a festa, paradoxalmente há um movimento de importação dos costumes franceses que, cada vez mais, admirava a cultura negra a partir do sucesso de Josephine Baker e os músicos de Jazz. A intelectualidade brasileira vê no carnaval a grande oportunidade de mostrar seu avanço para a modernidade. Além de absorver a cultura e o ritmo dos negros na arte popular brasileira para se inserir na imagem de uma nação que avança para um mundo moderno sem perder as tradições, se aproxima da elite francesa e faz com que a inserção das favelas e dos morros no fazer e exibir do carnaval, atraia o interesse do turista estrangeiro que vem em busca do outro, do exótico e do inusitado. Pois ao mesmo tempo, europeus e norte-americanos demonstram um despertar e um gosto para o aspecto étnico dessa mistura cultural e, dessa forma, o Brasil atrai esse olhar que vem em busca dos signos nacionais já conhecidos e identificados lá fora.

Embora esse novo formato ou gênero ainda precisasse ser reconhecido pela sociedade e pelos organizadores da festa oficialmente, era um prato cheio para os anseios da intelectualidade. Não seria tão difícil assim para a elite admitir esse protagonismo negro, já que o Carnaval era o tempo e o lugar de viver o que não se vivia no restante do ano. Era o lugar do sonho e da fantasia. Voltando ao princípio de inversão de papéis e possibilidade de vivenciar outros personagens da vida cotidiana no período de folia carnavalesca, duas figuras surgem para representar a miscigenação no Brasil, além de dar uma ideia de pacificação racial, com o aval da elite: o malandro e a baiana dos morros e das ruas cariocas.

A partir deste momento, essas características foram ficando cada vez mais evidentes e absorvidas pela sociedade. Carmen Miranda vendeu para o exterior uma imagem de baiana assim como Zé Carioca uma imagem de malandro gente boa. Artistas plásticos, escritores e músicos ajudaram a difundir essa imagem, reforçando e ressignificando estereótipos cunhados desde Jean-Baptiste Debret, Johann Moritz Rugendas e outros artistas viajantes, que desde sempre projetaram uma imagem de um Brasil africano, indígena, miscigenado e que estava, agora no século $\mathrm{XX}$, se aproveitando desse "mito de origem" para sair do atraso e avançar no mundo moderno.

\section{Referências}

ABREU, Martha. Cultura Popular, Um Conceito E Várias Histórias. In: Abreu, Martha e Soihet, Rachel, Ensino de História, Conceitos, Temáticas e Metodologias. Rio de Janeiro, Casa da Palavra, 2003.

CONDURU, Roberto. Arte Afro-Brasileira. Projeto pedagógico: Lúcia Gouvêa 
Pimentel e Alexandrino Ducarmo; Coord. Editorial: Fernando Pedro da Silva e Marília Andrés Ribeiro. - Belo Horizonte: C/ Arte, 2007.

CONDURU, Roberto e O'NEILL, Elena. (Org). Carl Einstein e a arte da África. Rio de Janeiro, EdUERJ, 2015.

FERREIRA, Felipe. Inventando carnavais: o surgimento do Carnaval carioca no século XIX e outras questões carnavalescas. Rio de Janeiro: Editora UFRJ, 2005.

FERREIRA, Felipe. O Livro de Ouro do Carnaval Brasileiro. Rio de Janeiro: Ediouro, 2004.

GOETHE, Johann Wolfgang Von. Viagem à Itália. Coordenação: Mario Luiz Frungillo; tradução Wilma Patrícia Maas. - São Paulo: Editora Unesp, 2017.

MALTA, Marize. Os modernismos das coisa e outras coisa do modernismo. In: 1922: Modernismo em debate - Culturas urbanas. São Paulo: Pinacoteca de São Paulo; Museu de Arte Contemporânea; Instituto Moreira Sales: 2021. Disponível em: https://www.youtube.com/watch?v=YRqYwSOvzKQ. <Acesso em 16 de junho de 2021, às 21h20>.

SCHWARCZ, Lilia Moritz. Brasil: uma biografia. Lilia Moritz Schwarcz e Heloisa Murgel Starling - $1^{\text {a }}$ Ed. - São Paulo: Companhia das Letras, 2015.

STOREY, John. Cultural theory and popular culture: a reader. / edited and introduced by John Storey. $2^{\text {a }}$ edição. London: 1998.

STOREY, John. Teoria cultural e cultura popular: uma introdução; Tradução de Pedro Barros. - São Paulo: Edições Sesc São Paulo, 2015.

TURANO, Gabriel da Costa; FERREIRA, Felipe. Incômoda vizinhança: a Vizinha Faladeira e a formação das escolas de samba no Rio de Janeiro dos anos 30. In: Textos escolhidos de cultura e arte populares, Rio de Janeiro, v.10, n.2, p. 65-92, Nov. 2013. 